\title{
Precipitation before Flowering Determined Effectiveness of Leaf Removal Timing and Irrigation on Wine Composition of Merlot Grapevine
}

\author{
Runze Yu ${ }^{1,2}$, Matthew W. Fidelibus ${ }^{1}$, James A. Kennedy ${ }^{3}$ and Sahap Kaan Kurtural ${ }^{1, *}$ (D) \\ 1 Department of Viticulture and Enology, University of California, Davis, 1 Shields Ave., Davis, CA 95616, USA; \\ crzyu@ucdavis.edu (R.Y.); mwfidelibus@ucanr.edu (M.W.F.) \\ 2 Department of Viticulture and Enology, California State University, Fresno, 2360 E. Barstow Ave. M/S VR 89, \\ Fresno, CA 93740, USA \\ 3 Functional Phenolics, LLC, 5305 River Rd, North Ste B, Keizer, OR 97303, USA; j.a.kennedy@outlook.com \\ * Correspondence: skkurtural@ucdavis.edu
}

check for updates

Citation: Yu, R.; Fidelibus, M.W.; Kennedy, J.A.; Kurtural, S.K. Precipitation before Flowering Determined Effectiveness of Leaf Removal Timing and Irrigation on Wine Composition of Merlot Grapevine. Plants 2021, 10, 1865. https: / / doi.org/10.3390/ plants10091865

Academic Editors: Franco Meggio and Paolo Sivilotti

Received: 2 August 2021

Accepted: 7 September 2021

Published: 9 September 2021

Publisher's Note: MDPI stays neutral with regard to jurisdictional claims in published maps and institutional affiliations.

Copyright: (c) 2021 by the authors. Licensee MDPI, Basel, Switzerland. This article is an open access article distributed under the terms and conditions of the Creative Commons Attribution (CC BY) license (https:/ / creativecommons.org/licenses/by/ $4.0 /)$.

\begin{abstract}
Grapevine productivity, and berry and wine flavonoid concentration, depend on the interactions of cultivar, environment, and applied cultural practices. We characterized the effects that mechanical leaf removal and irrigation treatments had on the flavonoid concentration of 'Merlot' (Vitis vinifera, L.) grape berries and wines in a hot climate over two growing seasons with contrasting precipitation patterns. Leaves were removed by machine, either at prebloom (PBLR), or at post-fruitset (PFLR), or not removed (control) and irrigation was either applied as sustained deficit irrigation $(\mathrm{SDI})$ at 0.8 of crop evapotranspiration $\left(\mathrm{ET}_{\mathrm{C}}\right)$ from budbreak to fruit set, or regulated deficit irrigation (RDI) at $0.8 \mathrm{ET}_{\mathrm{c}}$ from bud break to fruit set, $0.5 \mathrm{ET}_{\mathrm{c}}$ from fruit set to veraison, and $0.8 \mathrm{ET}_{\mathrm{c}}$ from veraison to harvest, of $\mathrm{ET}_{\mathrm{C}}$ In 2014, PFLR reduced the leaf area index (LAI) compared to control. The RDI decreased season-long leaf water potential ( $\left.\Psi_{\text {Int }}\right)$ compared to SDI. However, in 2015, none of the treatments affected LAI or $\Psi_{\text {Int }}$. In 2014, berry flavonoid concentrations were reduced by PBLR as well as SDI. SDI increased the flavonoid concentrations in wine, and PFLR increased some wine flavonols in one season. No factor affected the concentrations of wine proanthocyanidins or mean degree of polymerization. Thus, mechanical PFLR and RDI may increase berry flavonoid accumulation without yield reduction, in red wine grapes cultivars grown in hot climates when precipitation after bud break is lacking. However, spring precipitation may influence the effectiveness of these practices as evidenced by this work in a changing climate.
\end{abstract}

Keywords: canopy management; deficit irrigation; vineyard mechanization; flavonoids; hot climate viticulture

\section{Introduction}

The San Joaquin Valley (SJV) of California is a major wine grape growing region of the United States. In 2019, it produced $48 \%$ of the total wine grapes crushed in the state of California [1]. The average grower return for Merlot wine grapes from the SJV was only USD 310 per ton, whereas the state average for that variety was USD 826 per ton. Red wine grapes from this region are generally priced lower than similar grapes from cooler growing regions because its climate, specifically the high growing season temperatures and rapid growing degree day accumulation, favor high yields of fruit with relatively low berry flavonoid concertation at harvest. Hence, wines made of SJV grapes are usually marketed as high volume, low-cost wines. The economics of this industry favor the development of production practices that minimize grape and wine production cost while maintaining or improving grape and wine quality. For example, mechanization of canopy management practices and the implementation of optimal irrigation practices can minimize labor costs and improve grape berry flavonoid concentration [2-5]. 
Flavonoids are critical in determining the color, flavor, and mouthfeel of red wine [6] and thus directly affect wine quality [7]. They are also the primary antioxidants that help plants cope with environmental stresses. Their biosynthesis and concentration respond to environmental cues, including water deficits, solar radiation exposure, and temperature [8-10]. Previous studies observed that moderately increasing the severity of water deficits and solar radiation increased the content of two major flavonoid classes, anthocyanins and flavonols, in berries [8,11]. However, excessive exposure of grape berries to sunlight, high air temperatures, and water deficits, reduces these compounds at harvest $[10,12]$. Another major class of flavonoids, proanthocyanidins, determine wine astringency [13] and help stabilize wine color via copigmentation [14]. They are less sensitive to environmental stresses compared to other flavonoids [15]. However, under relatively severe environmental stress, even proanthocyanidin composition and concentrations may be altered, in a manner similar to the other flavonoids [16-18].

Leaf removal and deficit irrigation are the two cultural practices most commonly used to manage canopy structure and plant water status, other than dormant pruning. Leaf removal in the fruiting zone can directly affect canopy microclimate, and thereby affect berry flavonoid accumulation [3]. Leafing may affect grapevine source-sink relations, which would also contribute to the changes in berry development $[19,20]$. Removal of leaves around clusters of grapes at different developmental stages were investigated to help growers understand the various benefits selective leaf removal can provide. When leaves were removed early (prebloom), berry set, and therefore yield, were reduced in cool climate vineyards [21-23]. Studies in warm and hot climates deduced that early leaf removal increased berry total soluble solids (TSS), and berry skin flavonoid concentration without adversely affecting yield [3,24]. When leaves were removed later in the season in cool climates, the total proanthcoyanidin content was increased in berries, but decreased in wine [21]. Other studies suggested that late leaf removal could enhance berry anthocyanins $[3,25]$.

Water is a critical environmental factor for grapevine physiological development [26]. Water deficits reduce grapevine vegetative growth [27] and berry weight [28]. Severe water deficits might inhibit photosynthesis [29] and promote berry maturity and vine dormancy by stimulating abscisic acid biosynthesis [30], Mild to moderate water deficits improve berry chemical composition due, in part, to suppressing grapevine vegetative growth, and thereby increasing the sink strength of berries [31]. Moreover, water deficits increase berry flavonoid concentrations [32], and the increases in TSS and flavonoid concentrations can be attributed to the alteration of biosynthetic pathways [8,33], or simply the reduction in berry weight due to water loss [34,35].

Imposing water deficits on grapevines at different developmental stages can result in different effects. The SJV in California is a semiarid region and growers typically replace $70 \%$ to $80 \%$ of crop evapotranspiration from bud-break to harvest [2,35]. Preveraison water deficits increased berry anthocyanin concentration whereas post veraison water deficits promoted TSS concentration [32]. Castellarin et al. (2007) reported that preveraison water deficits hastened sugar accumulation and anthocyanin biosynthesis [8], where the genes related to anthocyanin biosynthesis, including flavonoid 3-hydroxylase (F3H), dihydroflavonol 4-reductase (DFR), UDP-glucose: flavonoid 3-O-glucosyl-transferase (UFGT) and glutathione S-transferase (GST) were upregulated. There was also evidence showing that both pre and postveraison water deficits can enhance anthocyanin biosynthesis [36]. Sometimes water deficits may increase the total anthocyanin content while the extractable anthocyanins might be lower [23]. Postveraison water deficits may also limit flavonoid biosynthetic accumulation [29]. Nevertheless, berry dehydration due to water deficits can overrule the metabolomic regulation and directly determine the flavonoid concentration in wine.

We previously studied the effects of mechanical leaf removal and water deficits on the anthocyanin content and profile of grape berries [3]. In this study, we subjected grapevines in a hot climate to mechanical canopy management treatments and water deficits in an 
attempt to promote flavonoid accumulation in grapes and wine. We hypothesized that the leaf removal and water deficit would improve the berry and wine flavonoid profile without adversely affecting yield. Overall, the objective of this study was to investigate the physiological and chemical impacts of mechanical leaf removal and water deficits on berry and wine flavonoid concentration of Merlot in a hot climate.

\section{Results}

\subsection{Weather at the Experiment Site}

The vineyard received approximately 34\% more precipitation in the 2014-2015 postharvest season (from September to April) than it did during the same time period in 2013-2014 (Figure 1A). The vineyard received little precipitation during the growing seasons, with only $1.4 \mathrm{~mm}$ and $10.2 \mathrm{~mm}$ of precipitation in 2014 and 2015, respectively. In the second season, precipitation prior to anthesis was higher than in 2014, and the GDD was also greater, $1711.8{ }^{\circ} \mathrm{C}$ GDD in 2015, versus $1590{ }^{\circ} \mathrm{C}$, in 2014 (Figure 1B). However, due to greater early season precipitation, in $2015, \Psi_{\text {leaf }}$ did not reach the water deficit threshold of $-1.0 \mathrm{MPa}$ to initiate irrigation until fruit set (Table 1). Due to the higher temperature from June to harvest, the $\mathrm{ET}_{\mathrm{c}}$ was higher in the second season, where $1151.1 \mathrm{~L}$ per vine were applied comparing to $1098 \mathrm{~L}$ per vine in 2014. Additionally, the applied water amounts of SDI were slightly different between two seasons, where there were $1483.0 \mathrm{~L}$ per vine applied in 2014 and 1423.6 L per vine applied in 2015.

A

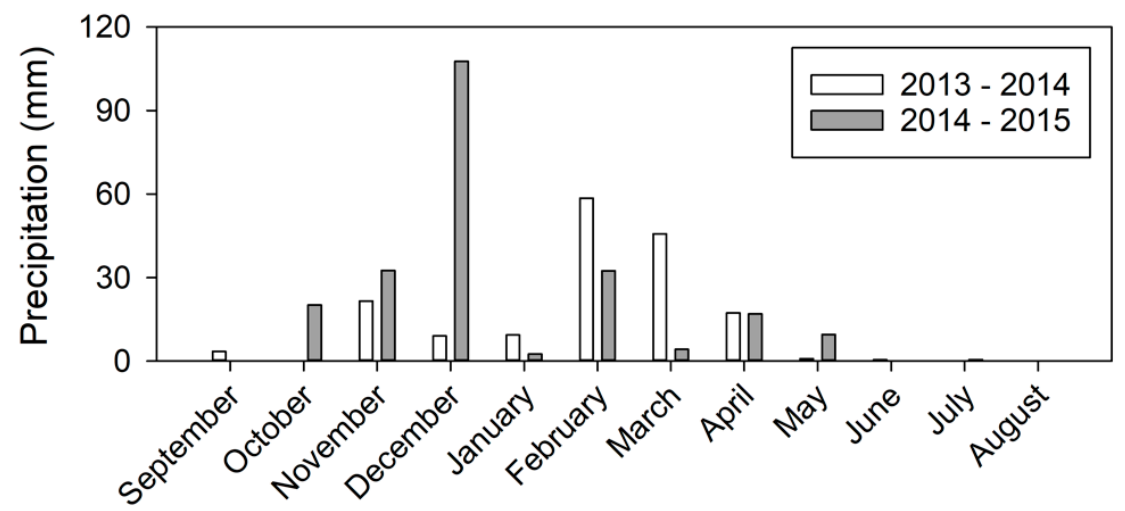

B

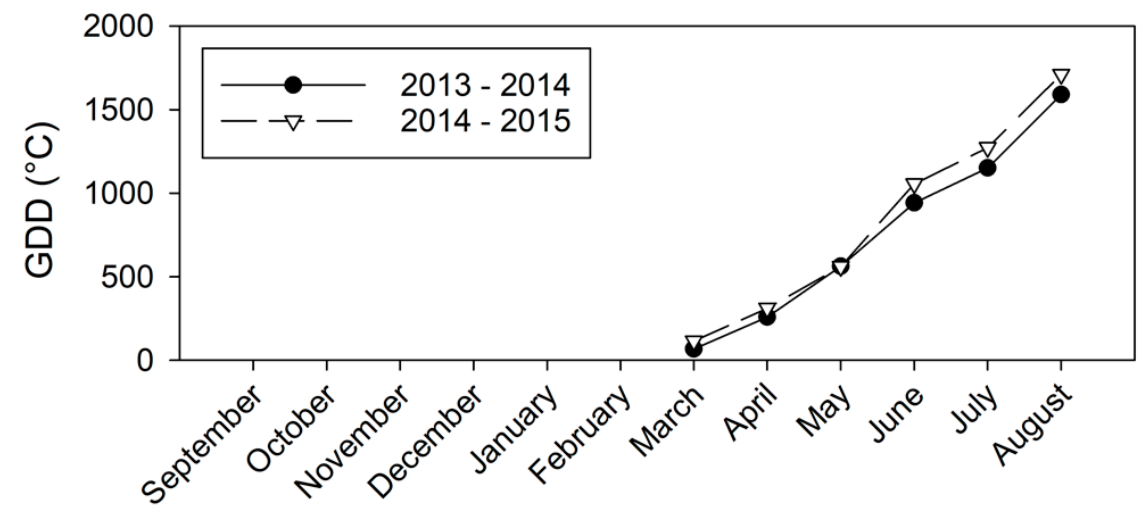

Figure 1. Weather at the experiment site in 2014 and 2015, acquired from California Irrigation Management Information System (CIMIS) station (\#206, Denair, CA). (A) Monthly precipitation. Note: GDDs were calculated until August, when the harvests in both years occurred. (B) Growing degree day accumulation starting in March of each year. 
Table 1. Crop evapotranspiration $\left(\mathrm{ET}_{\mathrm{C}}\right)$ and applied water amount between two irrigation regimes in a Merlot vineyard in Denair, California in 2014 and 2015.

\begin{tabular}{|c|c|c|c|c|c|c|c|c|}
\hline & \multicolumn{4}{|c|}{2014} & \multicolumn{4}{|c|}{2015} \\
\hline & \multicolumn{2}{|c|}{ SDI } & \multicolumn{2}{|c|}{ RDI } & \multicolumn{2}{|c|}{ SDI } & \multicolumn{2}{|c|}{ RDI } \\
\hline & $\mathrm{ET}_{\mathrm{c}}{ }^{\mathrm{a}}(\mathrm{mm})$ & $\begin{array}{c}\text { Applied } \\
\text { Water (L/vine) }\end{array}$ & $\mathrm{ET}_{\mathrm{c}}{ }^{\mathrm{a}}(\mathrm{mm})$ & $\begin{array}{c}\text { Applied } \\
\text { Water (L/vine) }\end{array}$ & $\mathrm{ET}_{\mathrm{c}}{ }^{\mathrm{a}}(\mathrm{mm})$ & $\begin{array}{c}\text { Applied } \\
\text { Water (L/vine) }\end{array}$ & $\mathrm{ET}_{\mathrm{c}}{ }^{\mathrm{a}}(\mathrm{mm})$ & $\begin{array}{c}\text { Applied } \\
\text { Water (L/vine) }\end{array}$ \\
\hline bud break-fruit set & 29.72 & 181.16 & 29.72 & 181.16 & $\mathrm{n} / \mathrm{a}^{\mathrm{b}}$ & $\mathrm{n} / \mathrm{a}^{\mathrm{b}}$ & $\mathrm{n} / \mathrm{a}^{\mathrm{b}}$ & $\mathrm{n} / \mathrm{a}^{\mathrm{b}}$ \\
\hline fruit set-veraison & 122.19 & 862.20 & 72.37 & 477.70 & 101.64 & 726.57 & 71.18 & 454.11 \\
\hline veraison-harvest & 61.49 & 439.60 & 61.49 & 439.60 & 97.50 & 696.99 & 97.50 & 696.99 \\
\hline total & 213.40 & 1482.96 & 163.58 & 1098.46 & 199.13 & 1423.55 & 168.68 & 1151.09 \\
\hline
\end{tabular}

a SDI utilized $80 \% \mathrm{ET}_{\mathrm{c}}$ from bud-break to harvest, for RDI utilized $80 \% \mathrm{ET}_{\mathrm{c}}$ from bud-break to fruit set, $50 \% \mathrm{ET}_{\mathrm{c}}$ from fruit set to veraison, and $80 \% \mathrm{ET}_{\mathrm{C}}$ from veraison to harvest. ${ }^{\mathrm{b}}$ Irrigation was not applied before the leaf water potential reached $-1 \mathrm{MPa}$. Hence, there was no water applied prior to fruit set in 2015.

\subsection{Canopy LAI and Season-Long Plant Water Status}

Canopy LAI and season-long $\Psi_{\text {Int }}$ were assessed in both seasons (Figure 2). In 2014, PFLR had significantly lower LAI when compared to Control (Figure 2A1). The LAI of grapevines subjected to PBLR was not different from Control, or PFLR, whereas in 2015, vines subjected to either LR treatment had similar LAI (Figure 2A2). Overall, vines had higher LAI in the second season compared to the first season. Season-long $\Psi_{\text {Int }}$ were $-1.3 \mathrm{MPa}$ with RDI in 2014, which was significantly lower than the -1.1 MPa of SDI (Figure 2B1). However, in 2015, there was no significant difference in $\Psi_{\text {Int }}$ between the treatments (Figure 2B2). We did not detect a significant interaction between leaf removal and irrigation on LAI or $\Psi_{\text {Int }}$ in either year of the experiment.
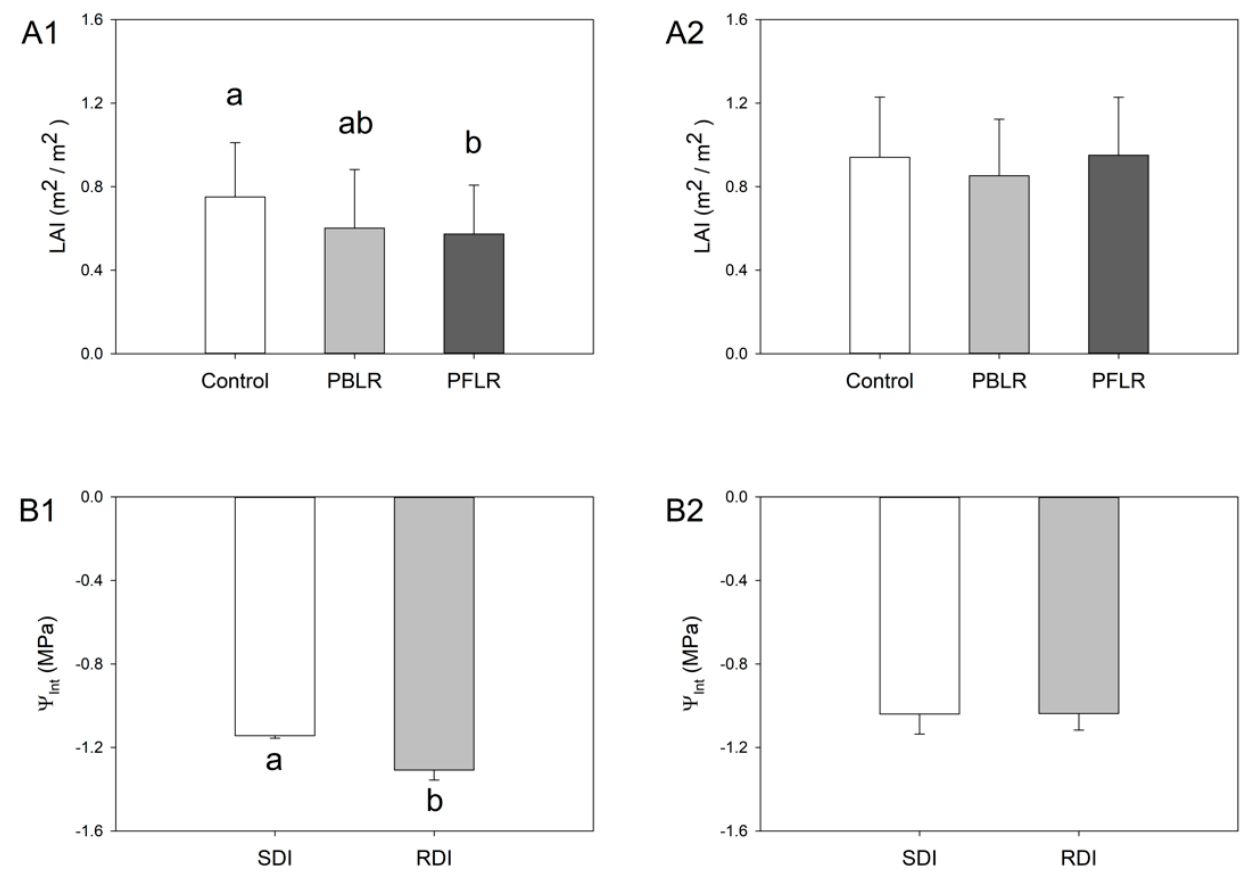

Figure 2. Grapevine leaf area index (LAI) and season-long leaf water potential integrals ( $\left.\Psi_{\text {Int }}\right)$ as affected by mechanical leaf removal treatments and deficit irrigation treatments, respectively. (1) 2014, (2) 2015, (A) LAI by mechanical leaf removal treatments, including untreated control (Control), prebloom leaf removal (PBLR), and post-fruit-set leaf removal (PFLR), (B) $\Psi_{\text {Int }}$ by deficit irrigation, including sustained deficit irrigation (SDI) and regulated deficit irrigation (RDI). Columns with different letters are significantly different at $p<0.05$ according to Tukey's HSD. 


\subsection{Yield Components and Berry Composition}

The yield results of the 2014 trial were previously reported [3]. In 2015, vines subjected to PBLR had the fewest clusters and lowest yield and average berry weight (Table 2). Vines subjected to RDI had fewer clusters than other vines. Irrigation treatments did not affect other yield components. Neither treatment affected the leaf area to fruit ratio in 2015. The berries were harvested at the similar maturity stages in 2014 and 2015. The TSS in 2015 was affected by the leaf removal treatments; where PRLR showed the highest TSS, PFLR showed the lowest.

Table 2. Yield components and berry primary metabolites at harvest in a Merlot vineyard in Denair, California in 2015 a,b,c .

\begin{tabular}{|c|c|c|c|c|c|c|c|c|c|c|}
\hline & & \multicolumn{6}{|c|}{ Components of Yield } & \multicolumn{3}{|c|}{ Berry Composition } \\
\hline & & Cluster/Vine & $\begin{array}{c}\text { Yield } \\
\text { (kg)/Vine }\end{array}$ & $\begin{array}{c}\text { Average } \\
\text { Berry wt. } \\
\text { (g) }\end{array}$ & $\begin{array}{l}\text { Skin } \\
\text { Mass } \\
\text { (mg) }\end{array}$ & $\begin{array}{c}\text { Skin to } \\
\text { Berry } \\
\text { Weight } \\
\text { Ratio (\%) }\end{array}$ & $\begin{array}{c}\text { Leaf Area } \\
\text { to Fruit } \\
\text { Ratio } \\
\left(\mathrm{m}^{2} / \mathrm{kg}\right)\end{array}$ & $\begin{array}{c}\text { TSS } \\
\left({ }^{\circ} \text { Brix }\right)\end{array}$ & $\mathrm{pH}$ & TA $(g / L)$ \\
\hline \multicolumn{11}{|c|}{2014} \\
\hline \multirow{4}{*}{ LR } & Control & $55^{\mathrm{a}}$ & $6.2^{\mathrm{a}}$ & 1.09 & $45.3^{\mathrm{a}}$ & $4.15^{\mathrm{a}}$ & 0.94 & 24.3 & 3.60 & 4.83 \\
\hline & PBLR & $54^{\mathrm{a}}$ & $6.1^{\mathrm{a}}$ & 1.07 & $42.9^{a b}$ & $4.00^{\mathrm{a}}$ & 0.87 & 24.1 & 3.62 & 4.66 \\
\hline & PFLR & $45^{b}$ & $4.5^{\mathrm{b}}$ & 1.11 & $39.5^{b}$ & $3.56^{\mathrm{b}}$ & 0.94 & 24.2 & 3.64 & 4.69 \\
\hline & $p$ value & $* *$ & $*$ & ns & $*$ & $*$ & ns & ns & ns & ns \\
\hline \multirow{3}{*}{ IRRI } & SDI & 52 & $6.1^{\mathrm{a}}$ & $1.14^{\mathrm{a}}$ & 42.7 & 3.83 & $0.79^{b}$ & $23.9^{b}$ & 3.63 & 4.83 \\
\hline & RDI & 51 & $5.3^{b}$ & $1.04^{\mathrm{b}}$ & 42.3 & 3.83 & $1.05^{\mathrm{a}}$ & $24.5^{\mathrm{a}}$ & 3.61 & 4.62 \\
\hline & $p$ value & ns & ns & $* *$ & ns & ns & * & ns & ns & ns \\
\hline \multicolumn{2}{|c|}{$\mathrm{LR} \times \mathrm{IRRI}$} & ns & * & ns & ns & ns & ns & ns & ns & ns \\
\hline & & & & & 2015 & & & & & \\
\hline \multirow{4}{*}{ LR } & Control & $120^{a}$ & $16.6^{\mathrm{a}}$ & $1.30^{\mathrm{a}}$ & 36.5 & 2.69 & 0.43 & $24.6^{\mathrm{ab}}$ & 3.48 & 7.53 \\
\hline & PBLR & $105^{b}$ & $13.4^{\mathrm{b}}$ & $1.27^{\mathrm{b}}$ & 37.4 & 2.92 & 0.49 & $24.9^{\mathrm{a}}$ & 3.50 & 7.90 \\
\hline & PFLR & $118^{a b}$ & $15.1^{\mathrm{ab}}$ & $1.32^{\mathrm{ab}}$ & 32.3 & 2.46 & 0.47 & $24.1^{\mathrm{b}}$ & 3.49 & 7.44 \\
\hline & $p$ value & $*$ & $* *$ & * & ns & ns & ns & $* *$ & ns & ns \\
\hline \multirow{3}{*}{ IRRI } & SDI & $120^{a}$ & 15.7 & 1.31 & 36.8 & 2.81 & 0.46 & 24.3 & 3.48 & 7.73 \\
\hline & RDI & $108^{b}$ & 14.4 & 1.33 & 34.0 & 2.57 & 0.47 & 24.8 & 3.50 & 7.52 \\
\hline & $p$ value & $* *$ & ns & ns & ns & ns & ns & ns & ns & ns \\
\hline \multicolumn{2}{|c|}{$\mathrm{LR} \times \mathrm{IRRI}$} & ns & ns & $\mathrm{ns}$ & ns & ns & ns & ns & ns & ns \\
\hline
\end{tabular}

a ANOVA to compare data ( $p$ value indicated); Letters within columns indicate significant mean separation according to Tukey's honestly significant difference test at $p$ value $\leq 0.05$, where " $* *: p$ value $\leq 0.05 ;$ “**”: $p$ value $\leq 0.001$. ${ }^{\mathrm{b}}$ LR: leaf removal; IRRI: irrigation; PBLR: prebloom leaf removal; PFLR: post-fruit-set leaf removal; ns: not significant. ${ }^{\mathrm{c}}$ A portion of this table was previously published $\odot 2015$ American Society for Enology and Viticulture AJEV 66:266-278.

\subsection{Berry Skin Flavonoid Concentration-Anthocyanins and Flavonols}

The concentration of berry skin flavonoids was measured in 2014 and 2015 (Table 3). In 2014, berries from vines subjected to PBLR had less delphinidin, cyanidin, and petunidin compared to berries from vines subject to the other two leaf removal treatments. The di-hydroxylated anthocyanins were the highest in berries from vines subjected to PFLR. In 2015, however, PFLR obtained the highest concentrations of malvidin and tri-hydroxylated anthocyanins. It also obtained the highest concentrations of quercetin, myricetin, and total flavonols in the second season. In 2014, RDI increased delphinidin, cyanidin, petunidin, tri-hydroxylated, and total anthocyanin. However, there was no difference in either anthocyanins or flavonols between SDI and RDI in 2015. When comparing the two years, the flavonoid concentrations in the second year were generally lower than the first. 
Table 3. Grape berry skin flavonoid concentration at harvest in a Merlot (Vitis vinifera L.) vineyard in Denair, California in 2014 and $2015^{\mathrm{a}, \mathrm{b}, \mathrm{c}}$.

\begin{tabular}{|c|c|c|c|c|c|c|c|c|c|c|c|c|}
\hline & & \multicolumn{8}{|c|}{ Anthocyanins } & \multicolumn{3}{|c|}{ Flavonols } \\
\hline & & \multicolumn{11}{|c|}{2014} \\
\hline & & Delphinidin & Cyanidin & Petunidin & Peonidin & Malvidin & $\begin{array}{c}\text { Tri- } \\
\text { hydroxylated }\end{array}$ & $\begin{array}{c}\text { Di- } \\
\text { hydroxylated }\end{array}$ & $\begin{array}{c}\text { Total } \\
\text { anthocyanins }\end{array}$ & Quercetin & Myricetin & $\begin{array}{c}\text { Total } \\
\text { flavonols }\end{array}$ \\
\hline \multirow{4}{*}{ LR } & Control & $11.06^{\mathrm{a}}$ & $6.56^{\mathrm{a}}$ & $11.94^{\mathrm{a}}$ & 17.32 & 94.05 & 117.05 & $23.88^{a b}$ & 140.93 & 13.33 & 0.73 & 14.06 \\
\hline & PBLR & $8.32^{b}$ & $5.45^{b}$ & $9.57^{b}$ & 15.56 & 85.70 & 103.59 & $21.01^{b}$ & 124.60 & 13.09 & 0.85 & 13.94 \\
\hline & PFLR & $11.19^{\text {a }}$ & $7.25^{\mathrm{a}}$ & $12.01^{\text {a }}$ & 18.86 & 90.52 & 113.72 & $26.11^{\text {a }}$ & 139.83 & 15.00 & 0.88 & 15.88 \\
\hline & $p$ value & $* *$ & * & $* *$ & ns & Ns & ns & $*$ & ns & ns & ns & ns \\
\hline \multirow{3}{*}{ IRRI } & SDI & $9.28^{b}$ & 6.73 & $10.43^{b}$ & 18.08 & 81.71 & $101.43^{b}$ & 24.81 & $126.24^{b}$ & 13.54 & 0.80 & 14.34 \\
\hline & RDI & $11.10^{\mathrm{a}}$ & 6.11 & $11.91^{\mathrm{a}}$ & 16.39 & 98.56 & $121.57^{\mathrm{a}}$ & 22.50 & $144.07^{\mathrm{a}}$ & 14.09 & 0.84 & 14.93 \\
\hline & $p$ value & * & ns & $*$ & ns & $* *$ & $* *$ & ns & $* *$ & ns & $\mathrm{ns}$ & ns \\
\hline \multicolumn{2}{|c|}{$\mathrm{LR} \times \mathrm{IRRI}$} & ns & ns & ns & ns & Ns & ns & ns & ns & ns & ns & ns \\
\hline & & & & & & 2015 & & & & & & \\
\hline \multirow{4}{*}{ LR } & Control & 7.89 & 5.29 & 8.92 & 16.67 & $70.46^{\mathrm{b}}$ & $87.27^{b}$ & 21.96 & 109.23 & $4.89^{b}$ & $1.71^{\mathrm{b}}$ & $7.81^{b}$ \\
\hline & PBLR & 8.47 & 5.65 & 9.35 & 18.28 & $70.88^{a b}$ & $88.70^{\mathrm{b}}$ & 23.93 & 112.64 & $6.35^{a b}$ & $1.88^{b}$ & $9.69^{a b}$ \\
\hline & PFLR & 8.91 & 5.76 & 10.33 & 18.44 & $85.96^{a}$ & $105.20^{a}$ & 24.21 & 129.40 & $7.41^{\mathrm{a}}$ & $2.36^{\mathrm{a}}$ & $11.53^{\mathrm{a}}$ \\
\hline & $p$ value & ns & ns & ns & ns & $*$ & $*$ & ns & ns & $* *$ & $*$ & $* *$ \\
\hline \multirow{3}{*}{ IRRI } & SDI & 8.19 & 5.60 & 9.31 & 17.63 & 74.46 & 91.96 & 23.24 & 115.19 & 6.17 & 1.96 & 9.58 \\
\hline & RDI & 8.66 & 5.53 & 9.76 & 17.96 & 77.08 & 95.49 & 23.49 & 118.98 & 6.27 & 2.02 & 9.78 \\
\hline & $p$ value & ns & ns & ns & ns & Ns & ns & ns & ns & ns & ns & ns \\
\hline \multicolumn{2}{|c|}{$\mathrm{LR} \times \mathrm{IRRI}$} & ns & ns & ns & ns & Ns & ns & ns & ns & ns & ns & ns \\
\hline \multicolumn{2}{|c|}{ Year } & $* *$ & $*$ & $*$ & ns & $* * *$ & $* * *$ & ns & $* *$ & $* * *$ & $* * *$ & $* * *$ \\
\hline \multicolumn{2}{|c|}{ Year × LR } & $*$ & ns & ns & ns & Ns & ns & ns & ns & ns & ns & ns \\
\hline \multicolumn{2}{|c|}{ Year × IRRI } & ns & ns & ns & ns & $*$ & ns & ns & ns & ns & ns & ns \\
\hline \multicolumn{2}{|c|}{ Year $\times$ LR $\times$ IRRI } & ns & ns & ns & ns & Ns & ns & ns & ns & ns & ns & ns \\
\hline
\end{tabular}

a ANOVA to compare data ( $p$ value indicated); Letters within columns indicate significant mean separation according to Tukey's honestly

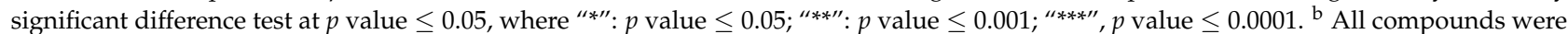
expressed as $\mathrm{mg}$ per $\mathrm{kg}$ of berry fresh weight. ${ }^{c}$ Abbreviations: LR: leaf removal; IRRI: irrigation; PBLR: prebloom leaf removal; PFLR: post-fruit-set leaf removal; SDI: sustained deficit irrigation; RDI: regulated deficit irrigation, ns: not significant.

\subsection{Wine Flavonoid Concentration}

Wine flavonoids were measured in 2014 and 2015, and differences observed in berry skins did not transfer into wine with leaf removal treatments (Table 4). In 2014 and 2015, there was no differences observed with leaf removal treatments in any of the anthocyanin derivatives. However, the differences in flavonols from leaf removal treatments were significant enough to be observed in wine, where PFLR had higher quercetin, myricetin, and total flavonols although there was no separation between PBLR and PFLR in 2015. As for irrigation treatments, in 2014, SDI increased the concentrations of cyanidin and petunidin, and also increased quercetin and total flavonols in both seasons. Like berry skin flavonoid concentrations, the concentrations of most of the wine anthocyanin and flavonol derivatives were lower in the second season than the first one.

Table 4. Wine flavonoid concentration in a Merlot (Vitis vinifera L.) vineyard in Denair, California in 2014 and 2015 a,b,c

\begin{tabular}{|c|c|c|c|c|c|c|c|c|c|c|c|c|}
\hline & & \multicolumn{8}{|c|}{ Anthocyanins } & \multicolumn{3}{|c|}{ Flavonols } \\
\hline & & \multicolumn{11}{|c|}{2014} \\
\hline & & Delphinidin & Cyanidin & Petunidin & Peonidin & Malvidin & $\begin{array}{c}\text { Tri- } \\
\text { hydroxylated }\end{array}$ & $\begin{array}{c}\text { Di- } \\
\text { hydroxylated }\end{array}$ & $\begin{array}{c}\text { Total } \\
\text { anthocyanins }\end{array}$ & Quercetin & Myricetin & $\begin{array}{c}\text { Total } \\
\text { flavonols }\end{array}$ \\
\hline \multirow{4}{*}{ LR } & Control & 3.98 & 1.86 & 8.19 & 2.11 & 128.23 & 140.40 & 3.97 & 144.37 & 19.56 & 6.70 & 26.26 \\
\hline & PBLR & 4.23 & 1.92 & 8.58 & 2.12 & 135.87 & 148.68 & 4.04 & 152.72 & 23.66 & 7.60 & 31.26 \\
\hline & PFLR & 4.44 & 2.25 & 9.31 & 2.42 & 124.73 & 138.49 & 4.68 & 143.16 & 24.05 & 7.67 & 31.72 \\
\hline & $p$ value & $\mathrm{ns}$ & ns & Ns & ns & ns & ns & ns & ns & ns & ns & ns \\
\hline \multirow{3}{*}{ IRRI } & SDI & 3.81 & $1.85^{b}$ & $7.80^{b}$ & 2.15 & 122.82 & 134.43 & 4.00 & 138.43 & $19.44^{b}$ & 6.59 & $26.03^{b}$ \\
\hline & RDI & 4.62 & $2.17^{\mathrm{a}}$ & $9.59^{a}$ & 2.29 & 136.40 & 150.61 & 4.46 & 155.07 & $25.40^{\mathrm{a}}$ & 8.06 & $33.46^{\mathrm{a}}$ \\
\hline & $p$ value & ns & * & $*$ & ns & ns & ns & ns & ns & * & ns & * \\
\hline \multicolumn{2}{|c|}{$\mathrm{LR} \times \mathrm{IRRI}$} & ns & ns & Ns & ns & ns & ns & ns & ns & ns & ns & ns \\
\hline
\end{tabular}


Table 4. Cont.

\begin{tabular}{|c|c|c|c|c|c|c|c|c|c|c|c|c|}
\hline & & \multicolumn{8}{|c|}{ Anthocyanins } & \multicolumn{3}{|c|}{ Flavonols } \\
\hline & & & & & & & 2015 & & & & & \\
\hline \multirow{4}{*}{ LR } & Control & 7.15 & 2.04 & 6.14 & 8.60 & 71.00 & 84.29 & 10.64 & 94.93 & $9.68^{b}$ & $3.71^{b}$ & $13.39^{b}$ \\
\hline & PBLR & 8.37 & 2.06 & 6.59 & 9.09 & 70.59 & 85.56 & 11.15 & 96.71 & $11.82^{a b}$ & $4.24 \mathrm{ab}$ & $16.05^{\mathrm{ab}}$ \\
\hline & PFLR & 9.31 & 2.55 & 7.67 & 10.35 & 85.21 & 102.20 & 12.89 & 115.09 & $12.71^{\mathrm{a}}$ & $4.72^{\mathrm{a}}$ & $17.43^{\mathrm{a}}$ \\
\hline & $p$ value & ns & ns & Ns & ns & ns & ns & ns & ns & * & $* *$ & * \\
\hline \multirow{3}{*}{ IRRI } & SDI & 7.64 & 2.21 & 6.60 & 9.03 & 72.58 & 86.82 & 11.24 & 98.06 & $10.16^{b}$ & $3.97^{b}$ & $14.13^{b}$ \\
\hline & RDI & 8.91 & 2.22 & 7.01 & 9.66 & 78.63 & 94.54 & 11.89 & 106.43 & $12.64^{\mathrm{a}}$ & $4.48^{\mathrm{a}}$ & $17.12^{\mathrm{a}}$ \\
\hline & $p$ value & ns & ns & $\mathrm{Ns}$ & ns & ns & ns & ns & ns & $*$ & $*$ & * \\
\hline \multicolumn{2}{|c|}{$\mathrm{LR} \times \mathrm{IRRI}$} & ns & ns & Ns & ns & ns & ns & ns & ns & ns & ns & ns \\
\hline \multicolumn{2}{|c|}{ Year } & $* * *$ & ns & $* *$ & $* * *$ & $* * *$ & $* * *$ & $* * *$ & $* * *$ & $* * *$ & $* * *$ & $* * *$ \\
\hline \multicolumn{2}{|c|}{ Year $\times$ LR } & ns & ns & Ns & ns & ns & ns & ns & ns & ns & ns & ns \\
\hline \multicolumn{2}{|c|}{ Year × IRRI } & ns & ns & Ns & ns & ns & ns & ns & ns & ns & ns & ns \\
\hline \multicolumn{2}{|c|}{ Year $\times$ LR $\times$ IRRI } & ns & ns & Ns & ns & ns & ns & ns & ns & ns & ns & ns \\
\hline
\end{tabular}

${ }^{a}$ ANOVA to compare data ( $p$ value indicated); Letters within columns indicate significant mean separation according to Tukey's honestly

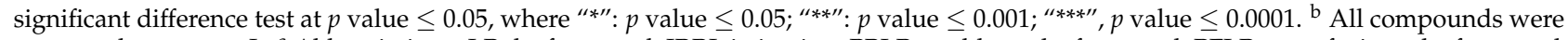
expressed as mg per L. ${ }^{c}$ Abbreviations: LR: leaf removal; IRRI: irrigation; PBLR: prebloom leaf removal; PFLR: post-fruit-set leaf removal; SDI: sustained deficit irrigation; RDI: regulated deficit irrigation; ns: not significant.

The wine proanthocyanidin concentration and composition were measured in 2014 and 2015 (Table 5). There were no significant differences in any of the proanthocyanidin subunits due to either leaf removal or deficit irrigation treatments, except epicatechin (EC) terminal subunits, which were reduced by PBLR in 2014. The general concentrations, including the total proanthocyanidins, were lower in the second season compared to the first season, and the $\mathrm{mDP}$ was higher.

Table 5. Wine proanthocyanidin subunit concentration in a Merlot (Vitis vinifera L.) vineyard in Denair, California in 2014 and $2015^{\mathrm{a}, \mathrm{b}, \mathrm{c}}$.

\begin{tabular}{|c|c|c|c|c|c|c|c|c|c|}
\hline & & \multicolumn{4}{|c|}{ Extension Subunits } & \multicolumn{2}{|c|}{ Terminal Subunits } & \multirow{2}{*}{$\begin{array}{c}\text { Total } \\
\text { Proanthocyanidins }\end{array}$} & \multirow{2}{*}{$\mathrm{mDP}$} \\
\hline & & EGC & $\mathrm{C}$ & EC & ECG & $\mathrm{C}$ & EC & & \\
\hline & & \multicolumn{8}{|c|}{2014} \\
\hline \multirow{4}{*}{ LR } & Control & 125.34 & 28.30 & 303.18 & 8.52 & 88.13 & $136.29^{a}$ & 689.76 & 3.09 \\
\hline & PBLR & 121.63 & 26.79 & 275.97 & 8.56 & 83.36 & $113.30^{\mathrm{b}}$ & 629.62 & 3.21 \\
\hline & PFLR & 123.49 & 28.67 & 286.42 & 7.86 & 92.06 & $128.50^{\mathrm{ab}}$ & 667.43 & 3.04 \\
\hline & $p$ value & ns & Ns & ns & ns & ns & * & ns & ns \\
\hline \multirow{5}{*}{ IRRI } & SDI & 123.93 & 29.44 & 291.60 & 7.58 & 88.84 & 132.45 & 673.84 & 3.06 \\
\hline & RDI & 124.06 & 26.37 & 286.31 & 9.09 & 87.18 & 120.19 & 652.63 & 3.15 \\
\hline & $p$ value & ns & Ns & ns & ns & ns & ns & ns & ns \\
\hline & & ns & Ns & ns & ns & ns & ns & ns & ns \\
\hline & & \multicolumn{8}{|c|}{2015} \\
\hline \multirow{4}{*}{ LR } & Control & 44.30 & 19.51 & 214.10 & 29.81 & 70.43 & 47.47 & 425.62 & 3.65 \\
\hline & PBLR & 49.41 & 20.29 & 229.99 & 31.80 & 71.52 & 49.02 & 452.03 & 3.79 \\
\hline & PFLR & 58.89 & 20.66 & 237.69 & 31.30 & 72.54 & 48.05 & 469.12 & 3.91 \\
\hline & $p$ value & ns & Ns & ns & ns & ns & ns & ns & ns \\
\hline \multirow{3}{*}{ IRRI } & SDI & 46.35 & 19.07 & 217.74 & 29.55 & 69.24 & 47.38 & 429.34 & 3.70 \\
\hline & RDI & 56.39 & 21.39 & 238.84 & 32.62 & 74.05 & 49.12 & 472.41 & 3.88 \\
\hline & $p$ value & ns & Ns & ns & ns & ns & ns & ns & ns \\
\hline \multicolumn{2}{|c|}{$\mathrm{LR} \times \mathrm{IRRI}$} & ns & Ns & ns & ns & ns & ns & ns & ns \\
\hline \multicolumn{2}{|c|}{ Year } & $* * *$ & $* * *$ & $* * *$ & $* * *$ & $* * *$ & $* * *$ & $* * *$ & $* * *$ \\
\hline \multicolumn{2}{|c|}{ Year × LR } & ns & Ns & ns & ns & ns & ns & ns & ns \\
\hline \multicolumn{2}{|c|}{ Year $\times$ IRRI } & ns & Ns & $\mathrm{ns}$ & ns & ns & ns & ns & ns \\
\hline \multicolumn{2}{|c|}{ Year $\times$ LR $\times$ IRRI } & ns & Ns & ns & ns & ns & ns & ns & ns \\
\hline
\end{tabular}

a ANOVA to compare data ( $p$ value indicated); Letters within columns indicate significant mean separation according to Tukey's honestly significant difference test at $p$ value $\leq 0.05$, where "**”: $p$ value $\leq 0.05 ;$ “ ${ }^{\prime * * * \prime \prime}, p$ value $\leq 0.0001 .{ }^{\mathrm{b}}$ All compounds were expressed as mg per L. ${ }^{c}$ Abbreviations: LR: leaf removal; IRRI: irrigation; PBLR: prebloom leaf removal; PFLR: post-fruit-set leaf removal; SDI: sustained deficit irrigation; RDI: regulated deficit irrigation; ns: not significant; C: (+)-catechin; EC: (-)-epicatechin; ECG: (-)-epicatechin-3-O-gallate; EGC: (-)-epigallocatechin; mDP: mean degree of polymerization. mDP was calculated as the ratio of total proanthocyanidins to the terminal subunits. 


\section{Discussion}

\subsection{Grapevine Canopy and Water Status}

Leaf removal can reduce canopy leaf area [37,38], as occurred with PFLR in 2014. Previous studies indicated grapevine canopies would regrow when leaves were removed early in the season $[19,22]$, which might partly explain why PBLR did not affect LAI. The second season had more precipitation between bud break to anthesis, which promoted vegetative growth, as observed from the generally higher LAI values in 2015. These results were corroborated by the relatively higher average $\Psi_{\text {Int }}$ of $-1.0 \mathrm{MPa}$ in the second season comparing it to the first season, which was $-1.2 \mathrm{MPa}$. Our results provided further evidence that leaf removal can be more effective in altering canopy size in more arid seasons, presumably because the drier soil made it easier to control canopy size by induced water deficits [39]

Application of the RDI treatment decreased $\Psi_{\text {Int }}$ in 2014, which indicated that the $30 \%$ reduction of applied water amounts between fruit set and verasion was sufficient to alter the season-long plant water status [2]. However, the second season did not show such a separation in season-long plant water status. We attributed this to the precipitation received before budbreak in 2015, which delayed the attainment of moderate water deficit stress as the $\Psi_{\text {leaf }}$ did not reach $-1.0 \mathrm{MPa}$ until fruit set.

\subsection{Yield Components and Berry Composition}

The effects of various timings of leaf removal on berry development and composition were previously investigated [21,38,40,41]. Late (post-fruit-set) leaf removal can affect grapevine yield and berry composition [38,42], but prebloom leaf removal has been shown to be more effective in modifying yield and berry composition than post-fruit-set leaf removal [21,43]. In our study, yield was reduced by PFLR in 2014, and by PBLR in 2015. This inconsistency might be due to treatment effects on LAI. Vines subjected to PFLR had the lowest LAI in 2014, perhaps sufficiently to reduce yield capacity compared to vines with larger canopies, as typically found in SJV [44]. Previous studies reported that berry weight may be affected by leaf removal, especially when the leaf removal was conducted early in the season $[19,37]$. Skin weight was affected by leaf removal, where altered canopy microclimate by leaf removal could be the direct factor to manipulate berry skin weight [22,45]. In our study, berry skin weight was reduced with PFLR in 2014. This might be because that late leaf removal diminished the growth of berry skin, as witnessed in previous studies [22,46].

Previous studies showed that leaf removal increased berry TSS concentration [19,47]. Leaf removal could increase berry TSS by dehydration sunlight [48,49], or increased carbohydrate accumulation and partitioning to the fruits [19]. However, in our study, treatments had few and small effects on TSS.

\subsection{Berry and Wine Flavonoids}

Previous studies investigated the effects of leaf removal on grape berry skin anthocyanin and flavonol concentration, and some studies focused on scrutinizing the various outcomes from the different timings of leaf removal [40,42]. However, in our case, PFLR was not effective in increasing berry skin anthocyanin concentration in either season. Previous work indicated that berry exposure to solar radiation late in the season might make the berries more prone to negative effects of radiation exposure and higher air temperature [24]. As for flavonols, they are generally reported to be sensitive to solar radiation [50,51], but we did not notice a difference in flavonols in 2014 even though the LAI was significantly reduced by PFLR. The berry weight might have been the determining factor, where PFLR did not significantly reduce berry weight, hence it did not increase the concentration either. When comparing the first season to the second, the anthocyanins and flavonols were generally lower, although the TSS at harvest in both years were at the same level. Previous studies reported that $<0.8-1.2 \mathrm{~m}^{2}$ of leaf area per $\mathrm{kg}$ of fruits could inhibit berry maturation [52]. The second season had a lower leaf area to fruit ratio-the plants did 
not have sufficient canopies as source tissues to reach the same maturity in both TSS and flavonoids, which might have contributed to the lower flavonoid accumulation in 2015.

RDI significantly reduced plant water status and increased berry anthocyanin concentrations in 2014. Previous studies had shown that deficit irrigation could increase berry anthocyanin concentration [8,33]. In our case, most of the anthocyanin derivatives were greater with RDI. As for flavonols, our study did not indicate that reduction of applied water amounts with RDI had noticeable influences on berry flavonols in either year. This agreed with previous work, that flavonols are relatively insensitive towards water deficits [8].

In our study, only a portion of the significant treatment effects on anthocyanins and flavonols were carried into wine. We attributed these discrepancies to differences in berry skin extractability affected by both treatments. Previous work indicated that higher permeability of the skin cell walls would lead to more advanced maturity, eventually increasing the extractability of flavonoids [53]. PBLR showed the ability to promote berry maturity (i.e., TSS) in 2014, and the more advanced maturity might have diminished flavonoid concentration benefiting from the leaf removal treatment. Some research attributed this observance to the warm and hot climate, where the impacts of leaf removal and deficit irrigation might be unhelpful in such regions, to a point that berry flavonoids are not increased, or are even decreased [10,54].

Among the three classes of flavonoids, proanthocyanidins are most the chemically stable and less easily manipulated by cultural practices or grapevine physiological status [55-57]. In our study, there were minimal effects from the treatments, where only EC terminal subunits were significantly affected. Some previous studies were able to see significant effects, mainly positive, of sun exposure and water deficits on berry or wine proanthocyanidin concentration $[15,16,58]$. However, in warm/hot climates, environmental stresses could be sufficiently severe to degrade berry proanthocyanidins $[59,60]$. This might have contributed to the lower total proanthocyanidin concentrations in the second season compared to the first due to the higher air temperatures in 2015. Among the proanthocyanidin subunits, the EGC extension subunits were the most drastically reduced in 2015. This was corroborated by previous work, where EGC extension subunits were sensitive towards air temperature [61].

\section{Materials and Methods}

\subsection{Site Description}

The experiment was conducted at a commercial vineyard in Stanislaus County, CA, USA. Merlot grapevines (clone FPS 01 ) grafted to Freedom ( $27 \% \mathrm{~V}$. vinifera hybrid) rootstock were planted in 1998 in $2.13 \mathrm{~m} \times 3.35 \mathrm{~m}$ (vine $\times$ row) spacing, in rows oriented NorthSouth. The grapevines were head-trained and supported with a California sprawl trellis which consisted of a cordon wire at $1.37 \mathrm{~m}$ above vineyard floor, and two foliage wires separated by a $20 \mathrm{~cm}$ t-top. The grapevines were cane-pruned to six canes with eight nodes each. The vineyard was drip-irrigated with pressure-compensating emitters spaced at $1.1 \mathrm{~m}$ with two emitters per vine delivering $2 \mathrm{~L} / \mathrm{h}$ each.

\subsection{Experimental Design}

The experiment was a three (leaf removal) $\times$ two (deficit irrigation) arranged factorially with a split-plot design with four replicated blocks. Three rows comprised one block and four buffer rows separated each block. The main plot was the leaf removal treatments, the subplot was irrigation treatments. Each experimental unit consisted of 285 vines, and 48 vines were selected, which were sampled and measured during the growing season.

\subsection{Mechanical Leaf Removal Treatments}

In 2014 and 2015, two leaf removal treatments were applied: a prebloom leaf removal treatment (PBLR), a post-fruit-set leaf removal treatment (PFLR), and an untreated control (Control). The leaf removal treatments were applied mechanically on the east side of the 
canopy with a roll-over type leaf remover (Model EL-50, Clemens Vineyard Equipment Inc., Woodland, CA, USA). A $50 \mathrm{~cm}$ window in the fruiting zone was created after the treatment. PBLR was applied at 200 GDD in 2014 and 2015. PFLR was applied at 644 GDD and 600 GDD in 2014, and 2015, respectively.

\subsection{Irrigation Treatments and Weather}

The amount of water to apply each week, crop evapotranspiration $\left(\mathrm{ET}_{\mathrm{c}}\right)$, was calculated as the product of reference evapotranspiration $\left(\mathrm{ET}_{\mathrm{O}}\right)$ and crop coefficient $\left(\mathrm{K}_{\mathrm{C}}\right)$ [62] The reference $\mathrm{ET}_{\mathrm{O}}$, air temperature, and precipitation were obtained from the California Irrigation Management Information System (CIMIS) weather station (\#206) in Denair, CA. For crop coefficient calculation, a neighboring row was irrigated to $100 \%$ of $\mathrm{ET}_{\mathrm{o}}$ replacement. The shade cast under 24 plants in this row then was measured to calculate percent shaded area to calculate the crop coefficient weekly. The crop evapotranspiration was then estimated as described by Williams and Ayars (2005) [63]. A sustained deficit irrigation (SDI) at $0.8 \mathrm{ET}_{\mathrm{C}}$ was applied weekly from anthesis until harvest. A regulated deficit irrigation (RDI) treatment was applied at $0.8 \mathrm{ET}_{\mathrm{C}}$ from anthesis to fruit set, $0.5 \mathrm{ET}_{\mathrm{C}}$ from fruit set to veraison, and back to $0.8 \mathrm{ET}_{\mathrm{C}}$ from veraison until harvest. The growing degree days (GDD) were calculated with the air temperature acquired from the CIMIS station as $\mathrm{GDD}=\left[\left(\mathrm{T}_{\max }+\mathrm{T}_{\min }\right) / 2-\mathrm{T}_{\text {ref }}\right]$, where $\mathrm{T}_{\max }$ was the maximum air temperature, $\mathrm{T}_{\min }$ was the minimum air temperature, and $\mathrm{T}_{\text {ref }}$ was the base temperature $10^{\circ} \mathrm{C}$. All other cultural practices were carried out according to University of California guidelines for the area. GDD calculation for both years only considered the time prior to harvest.

\subsection{Plant Water Status Assessment}

Leaf water potential ( $\Psi_{\text {leaf }}$ ) of the grapevines was monitored weekly. Four sun-exposed leaves were measured with the use of a pressure chamber (Model 610 Pressure Chamber Instrument., PMS Instrument Co., Corvallis, OR, USA) as previously reported elsewhere by Cook et al. (2015) [3]. To summarize the season-long plant water status, $\Psi_{\text {leaf }}$ integrals were calculated by using natural cubic splines. The values were then divided by the number of the days between the first and the last $\Psi_{\text {leaf }}$ water measurements in each year to make the data comparable to each individual measurement as $\Psi_{\text {Int }}$.

\subsection{Leaf Area Index and Yield Components}

Leaf area was determined at 50\% veraison from 24 vines per experimental unit. Four random shoots were collected from the east and west sides of the canopy per vine. The leaves were removed from the shoots, and the leaf area was measured with a leaf area meter (LI-3100C, LI-COR Biosciences, Lincoln, NE, USA). Total leaf area for each vine was calculated as the average leaf area per shoot multiplied by the average shoot numbers per vine. Lastly, leaf area index (LAI) was calculated as the ratio between the leaf area to the ground surface area for each vine $\left(7.14 \mathrm{~m}^{2}\right)$.

Yield components were measured on a single harvest date as the berry TSS reached $24{ }^{\circ}$ Brix in each year. All clusters in each treatment replicate were picked, counted, and weighed to determine the number of clusters per vine, average cluster weight, and yield per vine. Two sets of samples were collected, including one set of 100 berries to assess average berry mass, and another set of 20 berries to assess the dry skin mass and further skin flavonoid analysis.

\subsection{Chemicals}

All chromatographic solvents were of HPLC grade. Acetonitrile, acetone, ascorbic acid, ethanol, glacial acetic acid, maleic acid, methanol, potassium metabisulfite, potassium hydroxide, and sodium hydroxide were purchased from Fisher Scientific (Santa Clara, CA, USA). Phloroglucinol, (-)-epicatechin (EC), and hydrochloric acid were purchased from Sigma-Aldrich (St. Louis, MO, USA). Malvidin-3-O-glucoside and quercetin-3-O-rutinoside were purchased from Extrasynthése (Genay, France). Dihydrogen ammonium phosphate 
and phosphoric acid were purchased from VWR (Visalia, CA, USA). Hydrochloric acid and sodium acetate anhydrous were purchased from E. M. Science (Gibbstown, NJ, USA) and Mallinckrodt (Phillipsburg, NJ, USA), respectively.

\subsection{Berry Composition}

The first set of 100 berries were crushed and the juice was used for the analysis of berry primary metabolites, including TSS, titratable acidity (TA), and must $\mathrm{pH}$. Must TSS was measured (as ${ }^{\circ}$ Brix) with a digital refractometer (Atago PR-32, Atago CO., Ltd., Bellevue, WA, USA). The TA was measured by titrating the must to an endpoint $\mathrm{pH}$ of 8.2 with $0.1 \mathrm{~N}$ sodium hydroxide on an endpoint titrator (Mettler-Toledo DL15, Mettler-Toledo International Inc., Columbus, $\mathrm{OH}$, USA). Must $\mathrm{pH}$ was measured by a glass electrode $\mathrm{pH}$ meter (Accumet ${ }^{\mathrm{TM}}$ AB15, Fisher Scientific, Pittsburg, PA, USA).

\subsection{Extraction of Skin Flavonoids}

Berry skins were manually removed from the second berry set of 20 berries, and lyophilized with a centrivap (Centrivap Benchtop Centrifugal Vacuum Concentrator 7810014 equipped with Centrivap $-105^{\circ} \mathrm{C}$ Cold Trap 7385020, Labconco, Kansas City, MO, USA). Dry skin masses were recorded after lyophilization, and then extracted in $20 \mathrm{~mL}$ $66 \%\left(v \cdot v^{-1}\right)$ acetone solution in the dark for $24 \mathrm{~h}$. Acetone extracts were vacuum filtered, solids were discarded, and $1 \mathrm{~mL}$ of liquid was collected. The acetone in the extracts was removed with the Centrivap, and the solution left was brought up to $5 \mathrm{~mL}$ with water. Samples were then centrifuged for $15 \mathrm{~min}$ at $1400 \times g$, and the supernatant was filtered by PTFE membrane filters (diameter: $13 \mathrm{~mm}$, pore size: $0.45 \mu \mathrm{m}$, VWR, Seattle, WA, USA), and transferred into High Performance Liquid Chromatography (HPLC) vials before analysis.

\subsection{Berry and Wine Flavonoid Analysis}

Skin and wine anthocyanins and flavonols were analyzed by a reversed-phase HPLC system (Agilent 1100 series, Santa Clara, CA, USA) equipped with a system controller, a vacuum degasser (Model: G1379A), a quaternary pump (Model: G1311A), an autosampler, a thermostatted column compartment (Model: G1316A), and a DAD/UV-vis detector (Model: G1315A). A C18 column (LiChrosphere $100 \mathrm{RP}-18,4 \times 520 \mathrm{~mm}^{2}, 5 \mathrm{~mm}$ particle size, Agilent Technologies, Santa Clara, CA, United States) was used as previously reported elsewhere by Yu et al., (2016).

The concentrations for wine proanthocyanidin subunits were assessed by acid catalysis in the presence of excess phloroglucinol (phloroglucinolysis) by reversed-phase HPLC using the same instrument as mentioned above [64]. To purify proanthocyanidins, DSC-18 solid phase extraction (SPE) cartridges (bed weight: $500 \mathrm{mg}$, volume: $6 \mathrm{~mL}$, Sigma-Aldrich, St. Louis, MO, USA) were used. Briefly, the SPE column was preconditioned with 3 column volumes of methanol and then with 3 column volumes of water. We passed $1 \mathrm{~mL}$ of samples through the column and washed it by 3 column volumes of water to remove impurities. Then, the resided sample was eluted with $3 \times 3 \mathrm{~mL}$ of methanol. The eluent was lyophilized to powder and then re-dissolved in $1 \mathrm{~mL}$ of methanol and ready for phloroglucinolysis.

For phloroglucinolysis, $0.25 \mathrm{~mL}$ eluent was mixed with $0.25 \mathrm{~mL}$ of phloroglucinolysis reagent $\left(100 \mathrm{~g} \cdot \mathrm{L}^{-1}\right.$ phloroglucinol and $20 \mathrm{~g} \cdot \mathrm{L}^{-1}$ ascorbic acid with $0.2 \mathrm{~N}$ hydrochloric acid in methanol). The proanthocyanidin of interest in the mixture solution was reacted at $50{ }^{\circ} \mathrm{C}$ in water bath for $20 \mathrm{~min}$. Then, the reaction was stopped by mixing $200 \mu \mathrm{L}$ of the mixture solution with $1 \mathrm{~mL}$ of stopping reagent ( $40 \mathrm{mM}$ aqueous sodium acetate) and then directly transferred into HPLC vials. A column with two Chromolith RP-18e $\left(100 \times 4.6 \mathrm{~mm}^{2}\right)$ columns serially connected was used, and it was protected by a guard column with the same material $\left(4 \times 4 \mathrm{~mm}^{2}\right)$ from EM Science (Gibbstown, NJ, USA). The mobile phase flow rate was $3.0 \mathrm{~mL} \cdot \mathrm{min}^{-1}$, and two mobile phases were used, which included solvent $\mathrm{A}=1 \%$ aqueous acetic acid $\left(v \cdot v^{-1}\right)$ and solvent $\mathrm{B}=1 \%$ acetic acid in acetonitrile $\left(v \cdot v^{-1}\right)$. The HPLC flow gradient started with $97 \%$ A with 3\% B, 82\% A, 18\% B at $14 \mathrm{~min}, 20 \% \mathrm{~A}$, $80 \% \mathrm{~B}$ at $14.01 \mathrm{~min}, 97 \% \mathrm{~A}, 3 \% \mathrm{~B}$ at $16.01 \mathrm{~min}$ until $20 \mathrm{~min}$. The compound identification 
and quantification were conducted by using ChemStation version B.04.03 with the use of peak area measurements at $280 \mathrm{~nm}$ for all proanthocyanidin subunits. The standard used was (-)-epicatechin (Sigma-Aldrich, St. Louis, MO, USA).

\subsection{Winemaking}

We carried out microscale fermentations in 2014 and 2015. The fruits from the 24 vines were hand-harvested, and the 4 replicates of total $14 \mathrm{~kg}$ of fruits per treatment-replicate were used for fermentation. The fruits were crushed and destemmed by using a crusherdestemmer (Cantinetta C.d.A., ZAMBELLI Enotech, Camisano Vicentino, Italy), potassium metabisulfite was added to the must $\left(50 \mathrm{mg} \cdot \mathrm{kg}^{-1} \mathrm{SO}_{2}\right)$. The must from each treatment was then fermented in a $4 \mathrm{~L}$ vessel according to Sampaio et al. [65]. Briefly, each vessel was equipped with a Teflon cap, a fermentation airlock, and a food-grade polyethylene screen to keep must caps submerged in juice. Each lot was inoculated with $0.2 \mathrm{~g} \cdot \mathrm{L}^{-1}$ of commercial yeast, Saccharomyces cerevisiae Meyen ex Hansen (Cotes des Blancs, Red Star Yeast Prod. Oakland, CA, USA). All fermentations were carried out indoors with temperatures maintained at $23{ }^{\circ} \mathrm{C}$. Punch-downs were carried out twice a day, where the polyethylene screens were submerged, until the alcoholic fermentation was completed. The fermentation progress was monitored by a hydrometer until dryness. The wines were then pressed with a vacuum pump (MaximaDry ${ }^{\mathrm{TM}}$, Fisher Scientific, Waltham, MA, USA) with a pressure of $0.2 \mathrm{MPa}$ maintained for $30 \mathrm{~min}$, the crudes were removed by filter (P8, diameter: $11.0 \mathrm{~cm}$, Fisher Scientific, Waltham, MA, USA) placed in a Buchner funnel (CoorsTek 60242, Golden, $\mathrm{CO}, \mathrm{USA}$ ). Potassium metabisulfite was added to the wine to retain the $\mathrm{SO}_{2}$ level at $50 \mathrm{mg} \cdot \mathrm{kg}^{-1}$ and cold stabilized at $-2{ }^{\circ} \mathrm{C}$. Then, the wines were bottled in $375 \mathrm{~mL}$ glass bottles with screw caps.

\subsection{Statistical Analysis}

Interactions between year and treatments were tested and, whenever these interactions were significant $(p \leq 0.05)$, analysis was conducted separately for each year. The results were subjected to a two-way (leaf removal $\times$ irrigation) analysis of the variance (ANOVA) using in R (version 1.1.442, RStudio, Inc., Boston, MA, USA) appropriate for split-split plot with a factorial arrangement of treatments. All data were tested for normality using ShapiroWilk's test, some data required a combination of log and square root transformations where deemed necessary in 2014 and 2015. Treatment means were considered significantly different by Tukey's honestly significant difference adjustment at $p \leq 0.05$.

\section{Conclusions}

Leaf removal and water deficits have been extensively studied in viticultural research. However, there is a need to better understand the effects of different timings of mechanical leaf removal and deficit irrigation on grape berry and wine flavonoid concentration in hot climates where majority of the world's wine grapes are grown. Wine grape growers in hot climate regions must make up for relatively low prices, due to the low flavonoid concentration in grape berries/wine, with high yields of fruit without further compromising fruit quality. Thus, we studied two factors, leaf removal and deficit irrigation, to determine their effects on berry and wine flavonoid concentrations, to see if they may be useful to wine growers in hot climates. To conclude, we have determined PFLR and RDI in hot climates may increase flavonoid concentration in red wine grape berries but possibly not large enough of an effect to beneficially affect wine flavonoid concentration. Additionally, our study provides evidence on the feasibility of mechanical leaf removal and water deficits on the berry and wine quality improvement in large-acreage commercial vineyards in a hot climate where precipitation prior to anthesis is a determining factor of the effectiveness of cultural practices. Future work in the region may consider relating the soil water content, precipitation to anticipated fruit and wine composition. 
Author Contributions: Conceptualization, S.K.K.; methodology, S.K.K.; R.Y. and J.A.K.; data curation, R.Y.; writing — original draft preparation, R.Y. and S.K.K.; writing-review and editing, R.Y., M.W.F.; J.A.K., S.K.K. All authors have read and agreed to the published version of the manuscript.

Funding: The authors would like to acknowledge American Vineyard Foundation for partial funding during the execution of the study. A graduate student stipend was provided to RY by the Department of Viticulture and Enology, University of California, Davis.

Institutional Review Board Statement: Not applicable.

Informed Consent Statement: Not applicable.

Data Availability Statement: The raw data supporting the conclusions of this article will be made available by the authors, without undue reservation.

Acknowledgments: The authors would like to acknowledge Bronco Wine Company for allowing access to their vineyards and donation of the fruit during the execution of the experiment.

Conflicts of Interest: The authors declare no conflict of interest.

\section{References}

1. California Department of Food and Agriculture (CDFA). Grape Crush Report Final 2019; California Department of Food and Agriculture: Sacramento, CA, USA, 2020.

2. Terry, D.B.; Kurtural, S.K. Achieving Vine Balance of Syrah with Mechanical Canopy Management and Regulated Deficit Irrigation. Am. J. Enol. Vitic. 2011, 62, 426-437. [CrossRef]

3. Cook, M.G.; Zhang, Y.; Nelson, C.J.; Gambetta, G.; Kennedy, J.A.; Kurtural, S.K. Anthocyanin composition of Merlot is ameliorated by light microclimate and irrigation in central California. Am. J. Enol. Vitic. 2015, 66, 266-278. [CrossRef]

4. Yu, R.; Cook, M.G.; Yacco, R.S.; Watrelot, A.A.; Gambetta, G.; Kennedy, J.A.; Kurtural, S.K. Effects of Leaf Removal and Applied Water on Flavonoid Accumulation in Grapevine (Vitis vinifera L. cv. Merlot) Berry in a Hot Climate. J. Agric. Food Chem. 2016, 64, 8118-8127. [CrossRef]

5. Martínez-Lüscher, J.; Brillante, L.; Nelson, C.C.; Al-Kereamy, A.M.; Zhuang, S.; Kurtural, S.K. Precipitation before bud break and irrigation affect the response of grapevine 'Zinfandel'yields and berry skin phenolic composition to training systems. Sci. Hortic. 2017, 222, 153-161. [CrossRef]

6. Lorrain, B.; Ky, I.; Pechamat, L.; Teissedre, P.-L. Evolution of analysis of polyhenols from grapes, wines, and extracts. Molecules 2013, 18, 1076-1100. [CrossRef] [PubMed]

7. Ristic, R.; Bindon, K.; Francis, L.; Herderich, M.; Iland, P. Flavonoids and C13-norisoprenoids in Vitis vinifera L. cv. Shiraz: Relationships between grape and wine composition, wine colour and wine sensory properties. Aust. J. Grape Wine Res. 2010, 16, 369-388. [CrossRef]

8. Castellarin, S.D.; Matthews, M.A.; Di Gaspero, G.; Gambetta, G.A. Water deficits accelerate ripening and induce changes in gene expression regulating flavonoid biosynthesis in grape berries. Planta 2007, 227, 101-112. [CrossRef] [PubMed]

9. Cohen, S.D.; Tarara, J.M.; Kennedy, J.A. Assessing the impact of temperature on grape phenolic metabolism. Anal. Chim. Acta 2008, 621, 57-67. [CrossRef]

10. Torres, N.; Martínez-Lüscher, J.; Porte, E.; Kurtural, S.K. Optimal Ranges and Thresholds of Grape Berry Solar Radiation for Flavonoid Biosynthesis in Warm Climates. Front. Plant Sci. 2020, 11, 931. [CrossRef] [PubMed]

11. Martínez-Lüscher, J.; Sánchez-Díaz, M.; Delrot, S.; Aguirreolea, J.; Pascual, I.; Gomes, E. Ultraviolet-B radiation and water deficit interact to alter flavonol and anthocyanin profiles in grapevine berries through transcriptomic regulation. Plant Cell Physiol. 2014, 55, 1925-1936. [CrossRef]

12. Brillante, L.; Martínez-Lüscher, J.; Yu, R.; Plank, C.M.; Sanchez, L.; Bates, T.L.; Brenneman, C.; Oberholster, A.; Kurtural, S.K. Assessing spatial variability of grape skin flavonoids at the vineyard scale based on plant water status mapping. J. Agric. Food Chem. 2017, 65, 5255-5265. [CrossRef] [PubMed]

13. Sun, B.; de Sá, M.; Leandro, C.; Caldeira, I.; Duarte, F.L.; Spranger, I. Reactivity of Polymeric Proanthocyanidins toward Salivary Proteins and Their Contribution to Young Red Wine Astringency. J. Agric. Food Chem. 2013, 61, 939-946. [CrossRef]

14. Wrolstad, R.E.; Durst, R.W.; Lee, J. Tracking color and pigment changes in anthocyanin products. Trends Food Sci. Technol. 2005, 16, 423-428. [CrossRef]

15. Downey, M.O.; Harvey, J.S.; Robinson, S.P. The effect of bunch shading on berry development and flavonoid accumulation in Shiraz grapes. Aust. J. Grape Wine Res. 2004, 10, 55-73. [CrossRef]

16. Cortell, J.M.; Kennedy, J.A. Effect of shading on accumulation of flavonoid compounds in (Vitis vinifera L.) pinot noir fruit and extraction in a model system. J. Agric. Food Chem. 2006, 54, 8510-8520. [CrossRef] [PubMed]

17. Del Rio, J.L.P.; Kennedy, J.A. Development of proanthocyanidins in Vitis vinifera L. cv. Pinot noir grapes and extraction into wine. Am. J. Enol. Vitic. 2006, 57, 125-132. 
18. Torres, N.; Martínez-Lüscher, J.; Porte, E.; Yu, R.; Kaan Kurtural, S. Impacts of leaf removal and shoot thinning on cumulative daily light intensity and thermal time and their cascading effects of grapevine (Vitis vinifera L.) berry and wine chemistry in warm climates. Food Chem. 2021, 343, 128447. [CrossRef] [PubMed]

19. Palliotti, A.; Gatti, M.; Poni, S. Early Leaf Removal to Improve Vineyard Efficiency: Gas Exchange, Source-to-Sink Balance, and Reserve Storage Responses. Am. J. Enol. Vitic. 2011, 62, 219-228. [CrossRef]

20. Geller, J.P.; Kurtural, S.K. Mechanical canopy and crop-load management of Pinot gris in a warm climate. Am. J. Enol. Vitic. 2013, 64, 65-73. [CrossRef]

21. Kemp, B.S.; Harrison, R.; Creasy, G.L. Effect of mechanical leaf removal and its timing on flavan-3-ol composition and concentrations in Vitis vinifera L. cv. Pinot Noir wine. Aust. J. Grape Wine Res. 2011, 17, 270-279. [CrossRef]

22. Diago, M.P.; Ayestarán, B.; Guadalupe, Z.; Poni, S.; Tardáguila, J. Impact of prebloom and fruit set basal leaf removal on the flavonol and anthocyanin composition of Tempranillo grapes. Am. J. Enol. Vitic. 2012, 63, 367-376. [CrossRef]

23. Niculcea, M.; López, J.; Carmen Antolín, M. Involvement of berry hormonal content in the response to pre- and post-veraison water deficit in different grapevine (Vitis vinifera L.) cultivars. Aust. J. Grape Wine Res. 2014, 20, 281-291. [CrossRef]

24. Gatti, M.; Bernizzoni, F.; Civardi, S.; Poni, S. Effects of cluster thinning and preflowering leaf removal on growth and grape composition in cv. Sangiovese. Am. J. Enol. Vitic. 2012, 63, 325-332. [CrossRef]

25. Kotseridis, Y.; Georgiadou, A.; Tikos, P.; Kallithraka, S.; Koundouras, S. Effects of severity of post-flowering leaf removal on berry growth and composition of three red Vitis vinifera L. cultivars grown under semiarid conditions. J. Agric. Food Chem. 2012, 60, 6000-6010. [CrossRef] [PubMed]

26. Smart, R.E.; Coombe, B.G. Water relations of grapevines [Vitis]. Water Deficits Plant Growth 1983, 7, 137-196.

27. Escalona, J.M.; Bota, J.; Medrano, H. Distribution of leaf photosynthesis and transpiration within grapevine canopies under different drought conditions. VITIS-J. Grapevine Res. 2015, 42, 57. [CrossRef]

28. Santesteban, L.G.; Miranda, C.; Royo, J.B. Regulated deficit irrigation effects on growth, yield, grape quality and individual anthocyanin composition in Vitis vinifera L. cv. 'Tempranillo'. Agric. Water Manag. 2011, 98, 1171-1179. [CrossRef]

29. Herrera, J.C.; Hochberg, U.; Degu, A.; Sabbatini, P.; Lazarovitch, N.; Castellarin, S.D.; Fait, A.; Alberti, G.; Peterlunger, E. Grape metabolic response to postveraison water deficit is affected by interseason weather variability. J. Agric. Food Chem. 2017, 65, 5868-5878. [CrossRef]

30. Chaves, M.M.; Zarrouk, O.; Francisco, R.; Costa, J.M.; Santos, T.; Regalado, A.P.; Rodrigues, M.L.; Lopes, C.M. Grapevine under deficit irrigation: Hints from physiological and molecular data. Ann. Bot. 2010, 105, 661-676. [CrossRef] [PubMed]

31. Herrera, J.C.; Bucchetti, B.; Sabbatini, P.; Comuzzo, P.; Zulini, L.; Vecchione, A.; Peterlunger, E.; Castellarin, S.D. Effect of water deficit and severe shoot trimming on the composition of Vitis vinifera L. Merlot grapes and wines. Aust. J. Grape Wine Res. 2015, 21, 254-265. [CrossRef]

32. Intrigliolo, D.S.; Castel, J.R. Response of grapevine cv. 'Tempranillo' to timing and amount of irrigation: Water relations, vine growth, yield and berry and wine composition. Irrig. Sci. 2010, 28, 113. [CrossRef]

33. Bucchetti, B.; Matthews, M.A.; Falginella, L.; Peterlunger, E.; Castellarin, S.D. Effect of water deficit on Merlot grape tannins and anthocyanins across four seasons. Sci. Hortic. 2011, 128, 297-305. [CrossRef]

34. Medici, A.; Laloi, M.; Atanassova, R. Profiling of sugar transporter genes in grapevine coping with water deficit. FEBS Lett. 2014, 588, 3989-3997. [CrossRef]

35. Nelson, C.C.; Kennedy, J.A.; Zhang, Y.; Kurtural, S.K. Applied water and rootstock affect productivity and anthocyanin composition of Zinfandel in central California. Am. J. Enol. Vitic. 2016, 67, 18-28. [CrossRef]

36. Savoi, S.; Wong, D.C.J.; Degu, A.; Herrera, J.C.; Bucchetti, B.; Peterlunger, E.; Fait, A.; Mattivi, F.; Castellarin, S.D. Multi-Omics and Integrated Network Analyses Reveal New Insights into the Systems Relationships between Metabolites, Structural Genes, and Transcriptional Regulators in Developing Grape Berries (Vitis vinifera L.) Exposed to Water Deficit. Front. Plant Sci. 2017, 8, 1124. [CrossRef]

37. Tardáguila, J.; de Toda, F.M.; Poni, S.; Diago, M.P. Impact of Early Leaf Removal on Yield and Fruit and Wine Composition of Vitis vinifera L. Graciano and Carignan. Am. J. Enol. Vitic. 2010, 61, 372-381.

38. Poni, S.; Gatti, M.; Bernizzoni, F.; Civardi, S.; Bobeica, N.; Magnanini, E.; Palliotti, A. Late leaf removal aimed at delaying ripening in cv. Sangiovese: Physiological assessment and vine performance. Aust. J. Grape Wine Res. 2013, 19, 378-387. [CrossRef]

39. Brillante, L.; Martínez-Lüscher, J.; Kurtural, S.K. Applied water and mechanical canopy management affect berry and wine phenolic and aroma composition of grapevine (Vitis vinifera L., cv. Syrah) in Central California. Sci. Hortic. 2018, 227, 261-271. [CrossRef]

40. Tardáguila, J.; Diago, M.P.; Martínez de Toda, F.; Poni, S.; Vilanova, M. Effects of timing of leaf removal on yield, berry maturity, wine composition and sensory properties of cv. Grenache grown under non irrigated conditions. OENO One 2008, 42, 221-229. [CrossRef]

41. Sivilotti, P.; Falchi, R.; Herrera, J.C.; Škvarč, B.; Butinar, L.; Sternad Lemut, M.; Bubola, M.; Sabbatini, P.; Lisjak, K.; Vanzo, A. Combined Effects of Early Season Leaf Removal and Climatic Conditions on Aroma Precursors in Sauvignon Blanc Grapes. J. Agric. Food Chem. 2017, 65, 8426-8434. [CrossRef] [PubMed]

42. Feng, H.; Yuan, F.; Skinkis, P.A.; Qian, M.C. Influence of cluster zone leaf removal on Pinot noir grape chemical and volatile composition. Food Chem. 2015, 173, 414-423. [CrossRef] 
43. Scheiner, J.J.; Sacks, G.L.; Pan, B.; Ennahli, S.; Tarlton, L.; Wise, A.; Lerch, S.D.; Vanden Heuvel, J.E. Impact of Severity and Timing of Basal Leaf Removal on 3-Isobutyl-2-Methoxypyrazine Concentrations in Red Winegrapes. Am. J. Enol. Vitic. 2010, 61, 358-364.

44. Wessner, L.F.; Kurtural, S.K. Pruning Systems and Canopy Management Practice Interact on the Yield and Fruit Composition of Syrah. Am. J. Enol. Vitic. 2013, 64, 134-138. [CrossRef]

45. Pastore, C.; Zenoni, S.; Fasoli, M.; Pezzotti, M.; Tornielli, G.B.; Filippetti, I. Selective defoliation affects plant growth, fruit transcriptional ripening program and flavonoid metabolism in grapevine. BMC Plant Biol. 2013, 13, 30. [CrossRef] [PubMed]

46. Poni, S.; Bernizzoni, F.; Civardi, S.; Libelli, N. Effects of pre-bloom leaf removal on growth of berry tissues and must composition in two red Vitis vinifera L. cultivars. Aust. J. Grape Wine Res. 2009, 15, 185-193. [CrossRef]

47. Bubola, M.; Sivilotti, P.; Janjanin, D.; Poni, S. Early leaf removal has a larger effect than cluster thinning on grape phenolic composition in cv. Teran. Am. J. Enol. Vitic. 2017, 68, 234-242. [CrossRef]

48. Bergqvist, J.; Dokoozlian, N.; Ebisuda, N. Sunlight exposure and temperature effects on berry growth and composition of Cabernet Sauvignon and Grenache in the Central San Joaquin Valley of California. Am. J. Enol. Vitic. 2001, 52, 1-7.

49. King, P.D.; McClellan, D.J.; Smart, R.E. Effect of severity of leaf and crop removal on grape and wine composition of Merlot vines in Hawke's Bay vineyards. Am. J. Enol. Vitic. 2012, 63, 500-507. [CrossRef]

50. Sternad Lemut, M.; Sivilotti, P.; Franceschi, P.; Wehrens, R.; Vrhovsek, U. Use of Metabolic Profiling to Study Grape Skin Polyphenol Behavior as a Result of Canopy Microclimate Manipulation in a 'Pinot noir' Vineyard. J. Agric. Food Chem. 2013, 61, 8976-8986. [CrossRef]

51. Martínez-Lüscher, J.; Brillante, L.; Kurtural, S.K. Flavonol profile is a reliable indicator to assess canopy architecture and the exposure of red wine grapes to solar radiation. Front. Plant Sci. 2019, 10, 10. [CrossRef]

52. Kliewer, W.M.; Dokoozlian, N.K. Leaf area/crop weight ratios of grapevines: Influence on fruit composition and wine quality. Am. J. Enol. Vitic. 2005, 56, 170-181.

53. Bindon, K.A.; Madani, S.H.; Pendleton, P.; Smith, P.A.; Kennedy, J.A. Factors affecting skin tannin extractability in ripening grapes. J. Agric. Food Chem. 2014, 62, 1130-1141. [CrossRef]

54. Bonada, M.; Jeffery, D.W.; Petrie, P.R.; Moran, M.A.; Sadras, V.O. Impact of elevated temperature and water deficit on the chemical and sensory profiles of B arossa S hiraz grapes and wines. Aust. J. Grape Wine Res. 2015, 21, 240-253. [CrossRef]

55. Kennedy, J.A.; Matthews, M.A.; Waterhouse, A.L. Effect of maturity and vine water status on grape skin and wine flavonoids. Am. J. Enol. Vitic. 2002, 53, 268-274.

56. Ollé, D.; Guiraud, J.L.; Souquet, J.M.; Terrier, N.; Ageorges, A.; CheynierR, V.; Verries, C. Effect of pre- and post-veraison water deficit on proanthocyanidin and anthocyanin accumulation during Shiraz berry development. Aust. J. Grape Wine Res. 2011, 17, 90-100. [CrossRef]

57. Blancquaert, E.H.; Oberholster, A.; Ricardo-da-Silva, J.M.; Deloire, A.J. Grape flavonoid evolution and composition under altered light and temperature conditions in Cabernet Sauvignon (Vitis vinifera L.). Front. Plant Sci. 2019, 10, 1062. [CrossRef] [PubMed]

58. Cáceres-Mella, A.; Talaverano, M.I.; Villalobos-González, L.; Ribalta-Pizarro, C.; Pastenes, C. Controlled water deficit during ripening affects proanthocyanidin synthesis, concentration and composition in Cabernet Sauvignon grape skins. Plant Physiol. Biochem. 2017, 117, 34-41. [CrossRef] [PubMed]

59. Martínez-Lüscher, J.; Chen, C.C.L.; Brillante, L.; Kurtural, S.K. Partial solar radiation exclusion with color shade nets reduces the degradation of organic acids and flavonoids of grape berry (Vitis vinifera L.). J. Agric. Food Chem. 2017, 65, 10693-10702. [CrossRef]

60. Yu, R.; Brillante, L.; Martínez-Lüscher, J.; Kurtural, S.K. Spatial variability of soil and plant water status and their cascading effects on grapevine physiology are linked to berry and wine chemistry. Front. Plant Sci. 2020, 11, 790. [CrossRef] [PubMed]

61. Cohen, S.D.; Tarara, J.M.; Gambetta, G.A.; Matthews, M.A.; Kennedy, J.A. Impact of diurnal temperature variation on grape berry development, proanthocyanidin accumulation, and the expression of flavonoid pathway genes. J. Exp. Bot. 2012, 63, 2655-2665. [CrossRef] [PubMed]

62. Allen, R.G.; Pereira, L.S.; Raes, D.; Smith, M. Crop Evapotranspiration-Guidelines for Computing Crop Water Requirements; FAO Irrigation and Drainage Paper 56; FAO: Rome, Italy, 1998; Volume 300, p. D05109.

63. Williams, L.E.; Ayars, J.E. Grapevine water use and the crop coefficient are linear functions of the shaded area measured beneath the canopy. Agric. For. Meteorol. 2005, 132, 201-211. [CrossRef]

64. Kennedy, J.A.; Jones, G.P. Analysis of proanthocyanidin cleavage products following acid-catalysis in the presence of excess phloroglucinol. J. Agric. Food Chem. 2001, 49, 1740-1746. [CrossRef] [PubMed]

65. Sampaio, T.L.; Kennedy, J.A.; Vasconcelos, M.C. Use of Microscale Fermentations in Grape and Wine Research. Am. J. Enol. Vitic. 2007, 58, 534-539. 